\title{
USING WEB 2.0 TO LEARN THE SPANISH PRETÉRITO AND IMPERFECTO
}

\author{
Daniel A. Castaneda \\ Kent State University, Stark
}

\begin{abstract}
The researcher contrasted recognition of the Spanish preterite and imperfect by students who used web 2.0 technology with those who used electronic workbook technology. Results reveal that the use of web 2.0 technologies has a positive effect on learning the Spanish preterite and imperfect.
\end{abstract}

\section{INTRODUCTION}

The distinctions between the Spanish preterite and imperfect are considered difficult to learn by speakers of English learning Spanish (Ozete, 1998; Westfall \& Forester, 1996). Even near-native speakers of Spanish whose native tongue is English feel uncertain about the use of these grammatical structures (Salaberry, 2000) because English and Spanish signal the preterite and imperfect in different ways (Frantzen, 1995). In addition, these distinctions do not emerge in a balanced way during the early stages of learning. In other words, the preterite is the default marker of past, and the imperfect appears at a later stage of learning (Salaberry, 2000); in fact, a chronological bias may be at work when presenting these structures. Specifically, "most U.S. university textbooks introduce preterite forms before imperfect forms and preterite forms are introduced in isolation rather than in conjunction with imperfect forms" (Comajoan, 2005, p.41). The two structures have 
also received unequal attention in the literature. Researchers of second-language acquisition have documented the emergence and development of the preterite in some Romance languages, but equal amounts of research on the emergence and development of the imperfect have not been conducted (Bardovi-Harlig, 2005). Researchers should therefore investigate various types of instruction in the classroom and their effects on the use of the preterite and imperfect (Camojoan, 2005) as well as the various tasks and tools that facilitate the emergence of both grammatical forms at the early stages of learning. The purpose of this study was to investigate the effects of instruction in which web 2.0 technologies are used with students whose first language (L1) is English and who are learning the distinctions between Spanish preterite and imperfect.

\section{REVIEW OF LITERATURE}

\section{Spanish Preterite and Imperfect}

The distinctions between the Spanish preterite and imperfect are difficult to acquire by L1 English speakers learning Spanish because what these tenses convey differs in the two languages. For instance, the English simple past can signal either the preterite or imperfect in Spanish as shown in the following examples: "Peter said that Maria was pregnant." This sentence could be translated into the Spanish imperfect—Pedro dijo que María estaba embarazada —or the preterite-Pedro dijo que María estuvo embarazada (Montrul \& Slabakova, 1999). However, the context in which each aspect is used determines the meaning the speaker aims to convey.

For instance, Andersen (1991) exemplified these distinctions with a transcript of a native speaker who described a scene from a movie:

1. Nadie bailó tan bien como él.

Nobody danced as well as he (did).

2. Nadie bailaba tan bien como él.

Nobody danced as well as he (did).

Andersen further explained that the preterite, bailó, can be paraphrased and interpreted as in sentence (1) below; however, the imperfect may convey two senses as in sentences (2) and (3): 
Casteneda

(1) bailó: Nobody danced as well as he did in the dance context we just saw.

(2) bailaba: Nobody danced as well as he did when we were young.

(3) bailaba: Nobody danced as well as he did while everyone's eyes were fixed on him.

Andersen stated that the native speaker was trying to convey the meaning in sentence (3). Thus, English and Spanish signal the preterite and imperfect in different ways, and this is one of the most challenging grammatical structures for English speakers to grasp when learning Spanish.

\section{Learning the Spanish Preterite and Imperfect by Way of the Discourse Hypothesis}

Learning the preterite and imperfect has been studied from the perspective of two major hypotheses. First, the lexical aspect hypothesis states that "the inherent lexical meaning of the verb is determined by the temporal features intrinsic in the semantics of the predicate in its base form" (Salaberry, 2000, p. 17). These inherent semantic differences among verbs were classified into two major categories by Vendler (1967), who has been widely cited in contemporary linguistic and language acquisition studies. The telic category refers to verbs denoting accomplishments (e.g., build a house, run a mile) and achievements (e.g., arrive, leave, notice, and recognize). The atelic category refers to verbs denoting states (e.g., seem, know, need, want, and be) and activities (e.g., sleep, snow, play, and rain). Based on these differences, telic verbs are more likely inflected in the preterite, whereas atelic verbs are inflected using the imperfect (Lopez-Ortega, 2000).

Second, the discourse hypothesis maintains that the distribution of interlanguage verbal morphology is determined by narrative structure (Bardovi-Harlig, 1994). From this perspective, narrative discourse comprises foreground and background; that is, the core events narrated in a story plotline constitute the foreground, and the supporting information or elaboration and evaluation of the main points of the story constitute the background. In this sense, the preterite introduces a new reference in time (foreground) in the story, but the imperfect acts as a satellite (background) in the discourse (Blyth, 2005; Hopper, 1979; Lopez-Ortega, 2000; Ozete, 1988; Westfall \& Forester, 1996).

These hypotheses have been tested and supported, and some researchers have suggested that both are necessary to account for the distribution of tense-aspect morphology in second-language acquisition (Bardovi-Harlig, 1998; López-Ortega, 2000). The current study focused on the effects of learning and teaching the 
distinctions between the Spanish preterite and imperfect from the perspective of the discourse hypothesis; the rationale for taking this perspective was that it is the most widely and frequently used in current Spanish language learning textbooks.

\section{Use of Web 2.0 Technologies in This Study}

Web 2.0 technologies include "tools that support collaborative and individual text and multimedia production" (Sykes, Oskoz, \& Thorne, 2008, p. 530). The web 2.0 technologies used in this study were blogs, wikis, and YouTube videos.

A blog is a web 2.0 application in which users can share their thoughts, photos, or videos with others. Blog users can publish text and graphics without having sophisticated technical knowledge (Huffaker, 2005; Johnson, 2004; McIntosh, 2005). In academia, blogs can be used as e-portfolios, bulletin boards, or webpages (Campbell, 2003; Ducate \& Lomicka, 2005; Godwin-Jones, 2003). They can also be used to promote metacognitive skills, such as reflecting on one's own learning or the blog content itself (Downes, 2004; Mynard, 2007a, 2007b). In addition, blogs can be used as personal journals (Bloch, 2007; Thorne \& Payne, 2005), or they can facilitate collaborative work (Duffy \& Bruns, 2006; Lafford \& Lafford, 2005).

In second-language (L2) learning, some researchers have reported that blogs help to develop foreign-language linguistic skills (Montero-Fleta \& Pérez-Sabater, 2010) and facilitate cross-cultural exchanges (Lee, 2009). For example, they positively impact the learner's writing fluency and facilitate peer or teacher feedback, which can prompt further discussion and encourage focus on form for language accuracy (Lee, 2010b). Blogs also provide a platform for language learners to use the language actively and build or gain autonomy in the learning process (Bakar, 2009; Zeinstejer, 2008). Furthermore, blogs can promote extensive practice, learning motivation, authorship, and the development of rhetorical strategies (Bloch, 2007); moreover, they can help the learners to improve knowledge of the target culture (Le Ho, 2009).

A similar web 2.0 technology that can be used to share thoughts or other media is a wiki, which is "a freely expandable collection of interlinked Web 'pages,' hypertext system for storing and modifying information - a database, where each page is easily editable by any user with a forms-capable Web browser client" (Leuf \& Cunningham, 2001, p. 14). Wikis, good for online projects, use a simple set of commands (Bryant, 2006; Dobeli, 2005; Godwin-Jones, 2003). In addition, they are reliable and user-friendly (Konieczny, 2007). New contributions can be tracked, monitored, or restored to a previous version (Aronsson, 2002; Augar, Raitman, \& 
Zou, 2004; Sze, 2008). They can also promote a business skill needed by contemporary learners: collaboration (Parker \& Chao, 2007).

In L2 acquisition, wikis can help improve the writing proficiency of L2 students (Pae, 2007) and foster revision behavior (Arnold, Ducate \& Kost, 2009). Wikis can also foster attention and improve language accuracy through collaboration and scaffolding (Lee, 2010a). Similarly, wikis can foster students' attention to the development of content, rather than language accuracy, while co-constructing cultural knowledge (Kessler, 2009). In addition to supporting successful collaborative writing (Oskoz \& Elola, 2010), wikis can facilitate collective language production, network structure, and shared spaces in L2 (Lund, 2008) as well as promote visual literacy skills because they can be hyperlinked to other media (LuceKapler, 2007).

Another web 2.0 technology used to share thoughts and videos is YouTube. The video clips accessible though this portal "provide a huge multimedia library of real language use by real people, a potentially rich resource for language learning or corpus collection" (Godwin-Jones, 2007, p. 16). Because the YouTube portal is primarily used for video sharing, the students in this study did not post their writing assignments on this site; however, four video clips from this portal were carefully selected by the instructor, who posted the links on the course WebCT/Vista platform for easy access. The latter was done to make sure the students described the correct video clip. The participants' task was to write short stories based on these videos. The participants were given specific instructions on how to embed these videos into their blog or wiki.

In sum, web 2.0 technologies can be used for individual or collaborative work and have the potential to facilitate the learning of problematic grammar structures in a narrative context. In addition, they can help develop various skills necessary to learn a second language. Although research on web 2.0 related to the development of foreign-language linguistic skills is accumulating, few studies have focused on using web 2.0 to learn the Spanish preterite and imperfect (Castañeda, 2011; Castañeda, Ahern, \& Diaz, 2011).

\section{RESEARCH QUESTION}

The following research question guided the study: Does a significant difference exist in student recognition of distinctions between the Spanish preterite and 
imperfect based on the type of instruction (Web 2.0 vs. electronic workbook) while controlling for their pretest scores?

\section{METHOD}

\section{Participants}

The initial number of participants in this research study was 91 students enrolled in six sections of Elementary Spanish II during the 2009-2010 academic year. Of the total participants, 56 (61.5\%) were female and 35 (38.5\%) were male. Eightyeight (96.7\%) were native speakers of English, one (1.1\%) was a speaker of Spanish and English, and two (2.2\%) were speakers of Romanian and English. The age of these participants ranged from 18 to 45 years with a mean of 23.47 years and a standard deviation of 5.89. All participants were undergraduate students in a public university in the American Midwest.

Although the initial number of participants was 91, the final number of participants was 63 ( $n=30$ for the experimental group and $n=33$ for the control group) because some students dropped out or were absent during data collection.

\section{Materials}

All participants in this study completed a survey containing demographic information, such as age, gender, first language, and major among others. In addition, they completed a pre- and a posttest, which were identical (See Appendix A). The participants were asked to choose one option among four alternatives for specific verbs (present, preterite, imperfect, and infinitive). This test was validated by the researcher (a member of the experimental group), and two professors (members of the control group), who took into account guidelines suggested by Rubio, Ber-Weger, Tebb, and Rauch (2003). This validation was done in order to ensure that the wording of each item in the instrument was clear for the target population and to determine whether the items were representative for data collection purposes. The results showed an interrater agreement of $1.0(100 \%)$ for representation and clarity. The results suggested a consistency among all instructors in this study. In order to help the students understand the sequence of events, a YouTube video about Los Tres Osos (The Three Bears) was shown once. The participants were asked to select the correct choice of verbs after watching the video clip. 
Casteneda

\section{Procedure}

After receiving approval from the Institutional Review Board of Kent State University to recruit and work with human subjects, three sections served as the experimental group and were taught by the researcher. The three other sections, taught by three different instructors, served as the control group. The language department where the study was conducted supplied all instructors with syllabi, tests, and grading criteria guidelines. The textbook used for this level was accompanied by an electronic workbook, hosted on the Quia website, www.books.quia.com. Students in both the experimental and the control group submitted their homework related to listening, speaking, reading, and writing activities via this platform; however, for the purposes of this research study, the writing activities (open-ended narrations) related to the preterite and imperfect were submitted via a web 2.0 technology (blog or wiki) by the experimental group, whereas the control group participants used the electronic workbook. The openended narrations were given as the culminating activity after the instructors in the experimental and control group presented each grammar topic following the textbook organization sequence: the introduction to each grammar structure, presentation of regular and irregular verbs, and the contrasts of both structures. The writing tasks in the experimental and control group were supplementary to normal classroom instruction.

With respect to group dynamics, the participants in the control group worked individually. Within the experimental group, the blog group worked individually, but the participants in the wiki group worked collaboratively and were divided into smaller groups of three or four. The rationale is that blogs are mostly set up for personal use (Ducate \& Lomicka, 2005) and wikis are used more often in collaborative writing (Oskoz \& Elola, 2010).

The students in the experimental group and the control group wrote a total of four postings. The experimental group wrote short stories (fictional narratives) based on YouTube video clips, and the control group wrote short stories based on personal experiences (See Appendix B). The rationale for using fictional narratives in the experimental group and personal narratives in the control groups was to see the impact of the writing task with regard to the emergence of the preterite or imperfect. Previous studies have indicated that at an early stage of learning, more preterite than imperfect forms were used in fictional narratives, but more imperfect than preterite forms were used in personal narratives (Liskin-Gasparro, 2000; Salaberry, 2003). The YouTube videos used in this study corresponded to the Spanish versions of well-known fairy tales - Los Tres Cerditos (The Three Little 
Pigs), La Caperucita Roja (The Red Riding Hood) - and two clips from The Great Dictator and Modern Times, two silent movies. The specific sequences in the silent movies are known as Searching for Smuggled "Nose-Powder" and Hungarian Dance No. 5, respectively. The writing tasks for both groups were open-ended, and students were required to submit two drafts for each posting. All participants in this study received feedback after the first draft in the form of revision prompts. The students' mistakes were not corrected by the instructor or the software; specifically, students were asked to revise not only the preterite and imperfect but also other aspects of writing, such as spelling, agreement, and pronouns.

\section{RESUlTS}

A one-way ANCOVA was conducted to compare the effectiveness in achievement of learning the distinctions of Spanish preterite and imperfect between the two groups for recognition. The dependent variable was the students' postscores, and the independent variable was the type of instruction (web 2.0 or electronic workbook). The rationale for using an ANCOVA is that it allowed the researcher to explore the differences between two groups while statistically controlling for an additional variable (covariate) that may influence the dependent variable (postscores) (Hinkle, Wiersma, \& Jurs, 2003). Because most students may have studied the preterite and imperfect in previous courses in high school, the researcher carefully selected the participants' previous knowledge (pretest scores) as the covariate; that is, the researcher increased the precision of the quantitative analysis by reducing the error variance by statistically controlling for the participants' pretest scores on this grammar structure. The results are presented in the tables below followed by a brief explanation.

Table 1: Whether Respondent Was in the Web 2.0 (Wiki/Blog) or Control Group

Dependent Variable Respondents' post test

\begin{tabular}{lcrrr}
\hline \hline Whether respondent was & & & \multicolumn{2}{c}{$95 \%$ Confidence Interval } \\
\cline { 4 - 5 } in the wiki or control group & Mean & Std. Error & Lower Bound & Upper Bound \\
\hline $\begin{array}{l}\text { Respondent was in the } \\
\text { wiki group }\end{array}$ & $16.779^{\mathrm{a}}$ & 1.230 & 14.318 & 19.240 \\
$\begin{array}{l}\text { Respondent was in the } \\
\text { blog group }\end{array}$ & $21.793^{\mathrm{a}}$ & 1.929 & 17.932 & 25.654 \\
$\begin{array}{l}\text { Respondent was in the } \\
\text { control group }\end{array}$ & $14.439^{\mathrm{a}}$ & .975 & 12.487 & 16.391 \\
\hline \hline
\end{tabular}

a. Covariates appearing in the model are evaluated at the following values: Respondents' pretest $=4.9524$. 
Casteneda

In Table 1, the postscore means suggest that overall the students in the experimental group (web 2.0 technologies) outperformed those in the control group (electronic workbooks). Within the experimental group, the bloggers performed better than the wiki users.

Table 2: Tests of Between-Subjects Effects

\begin{tabular}{|c|c|c|c|c|c|c|c|c|}
\hline Source & $\begin{array}{l}\text { Type III Sum } \\
\text { of Squares }\end{array}$ & $d f$ & Mean Square & $\mathrm{F}$ & Sig. & $\begin{array}{l}\text { Partial Eta } \\
\text { Squared }\end{array}$ & $\begin{array}{l}\text { Noncent. } \\
\text { Parameter }\end{array}$ & $\begin{array}{l}\text { Observed } \\
\text { Power }^{b}\end{array}$ \\
\hline Corrected Model & $721.438^{a}$ & 3 & 240.479 & 7.674 & .000 & .281 & 23.021 & .983 \\
\hline Intercept & 6373.869 & 1 & 6373.869 & 203.387 & .000 & .775 & 203.387 & 1.000 \\
\hline Pretest scores & 189.501 & 1 & 189.501 & 6.047 & .017 & .093 & 6.047 & .677 \\
\hline Web2.0 vs control & 371.549 & 2 & 185.775 & 5.928 & .005 & .167 & 11.856 & .861 \\
\hline Error & 1848.975 & 59 & 31.339 & & & & & \\
\hline Total & 19247.000 & 63 & & & & & & \\
\hline Corrected Total & 2570.413 & 62 & & & & & & \\
\hline
\end{tabular}

a. $\mathrm{R}$ Squared $=.281$ (Adjusted R Squared $=.244)$

b. Computed using alpha $=.05$

As shown in Table 2, the analysis revealed a significant relationship between the covariate and the dependent variable $F(1,59)=6.05, p=.017$. After adjusting the preintervention scores, the results revealed statistical significance between the experimental and the control group $F(1,59)=5.93, p=.005, \eta^{2}=.17$.

Table 3: Multiple Comparisons

\begin{tabular}{|c|c|c|c|c|c|c|}
\hline \multicolumn{7}{|l|}{$\begin{array}{l}\text { Respondents' post test } \\
\text { Tukey HSD }\end{array}$} \\
\hline \multirow{2}{*}{$\begin{array}{l}\text { (I) Whether respondent } \\
\text { was in the web } 2.0 \\
\text { (wiki/blog) or control } \\
\text { group }\end{array}$} & \multirow{2}{*}{$\begin{array}{l}(\mathrm{J}) \text { Whether respondent } \\
\text { was in the wiki/blog or } \\
\text { control group }\end{array}$} & \multirow{2}{*}{$\begin{array}{c}\text { Mean } \\
\text { Difference (I- } \\
\mathrm{J})\end{array}$} & \multirow[b]{2}{*}{ Std. Error } & \multirow[b]{2}{*}{ Sig. } & \multicolumn{2}{|c|}{ 95\% Confidence Interval } \\
\hline & & & & & Lower Bound & Upper Bound \\
\hline \multirow[t]{2}{*}{$\begin{array}{l}\text { Respondent was in the } \\
\text { wiki group }\end{array}$} & $\begin{array}{l}\text { Respondent was in the } \\
\text { blog group }\end{array}$ & $-5.7000^{*}$ & 2.15662 & .027 & -10.8692 & -.5308 \\
\hline & $\begin{array}{l}\text { Respondent was in the } \\
\text { control group }\end{array}$ & 2.8889 & 1.50994 & .143 & -.7303 & 6.5080 \\
\hline \multirow[t]{2}{*}{$\begin{array}{l}\text { Respondent was in the } \\
\text { blog group }\end{array}$} & $\begin{array}{l}\text { Respondent was in the } \\
\text { wiki group }\end{array}$ & $5.7000^{*}$ & 2.15662 & .027 & .5308 & 10.8692 \\
\hline & $\begin{array}{l}\text { Respondent was in the } \\
\text { control group }\end{array}$ & $8.5889^{*}$ & 2.04818 & .000 & 3.6796 & 13.4981 \\
\hline \multirow[t]{2}{*}{$\begin{array}{l}\text { Respondent was in the } \\
\text { control group }\end{array}$} & $\begin{array}{l}\text { Respondent was in the } \\
\text { wiki group }\end{array}$ & -2.8889 & 1.50994 & .143 & -6.5080 & .7303 \\
\hline & $\begin{array}{l}\text { Respondent was in the } \\
\text { blog group }\end{array}$ & $-8.5889^{*}$ & 2.04818 & .000 & -13.4981 & -3.6796 \\
\hline
\end{tabular}

Based on observed means.

The error term is Mean Square(Error) $=32.831$.

*. The mean difference is significant at the 0.05 level.

In Table 3, post-hoc comparisons using a Tukey HSD test indicated that the mean score for the blog group $(M=23, S D=5.7)$ differed significantly from the wiki group $(M=16.4, S D=4.7)$ and the control group $(M=14.3, S D=6.5)$. The 
control group $(M=14.3, S D=6.5)$ did not differ significantly from the wiki group $(M=16.4, S D=4.7)$.

Taken together, the results shown in the tables above suggested that instruction that uses web 2.0 technologies affects positively the learning of the Spanish preterite and imperfect

\section{DISCUSSION}

These findings support the idea that instruction and writing tasks incorporating web 2.0 technologies significantly affect students' achievement of recognition of the difference between preterite and imperfect.

More specifically, blog and wiki users combined performed better than the electronic workbook users (see Tables 1 and 2). These results suggest that the nature and interface of web 2.0 technologies may better suit this type of open-ended interactive writing activities than the similar activities in the electronic workbook For instance, blog and wiki technologies facilitate the interaction of the students with their peers and instructor beyond what occurs in the traditional face-to-face classroom. These technologies also allow the students to access their document on the web where one or multiple users can edit, revise, or add information. What's more, students can customize their platform (e.g., posting a profile picture) and link the document to other web 2.0 technology, such as YouTube video. By contrast participants using the electronic workbook (control group) have an interface that is one-sided, noncommunicative, impersonal, and not collaborative. In other words they cannot customize or control the electronic workbook interface or interact with their peers.

The YouTube videos seem to help the participants balance the emergence of both grammatical structures. The participants in the experimental group were required to watch the clips at least twice. During the first viewing, they were asked to focus on the salient events of the movie, such as activities in succession. During the second viewing they were asked to focus on the setting of the story, such as describing a landscape, scenery, or the decoration of a room. Asking the students to follow this pattern for each posting helped them acquire an organized and systematic way to distinguish the Spanish preterite from the imperfect in a narrative, suggesting that the distinctions between the preterite and imperfect may be best learned using visual media as advocated by Blyth (2005). 
Group dynamics (individual vs. collaborative work) neither favored nor had a negative effect on student achievement. Blog and electronic workbook users wrote individually and had more autonomy over their postings; however, electronic workbook users did not perform as well as the blog users. By contrast, the wiki users had a more challenging task because they had to collaborate and synchronize their postings with their peers. Despite this challenge, wiki users outperformed the electronic workbook users (see Table 1); however, discovering why blog users stand out among all groups (see tables 1 and 3 ) remains a subject of further interest. One possible explanation is that the blog users had a better interface than the electronic workbook users and a less challenging task than the wiki users, who had to write collaboratively. A future study may explain these differences.

With regard to the learning of the Spanish preterite and imperfect, previous studies have shown that beginners use the imperfect more often than the preterite in personal narratives, whereas in fictional narratives students use the preterite more often than the imperfect (Liskin-Gasparro, 2000; Salaberry, 2003). In theory, the participants in the control group had an advantage over the experimental group because they used personal narratives and were more prone to use the imperfect; however, the results of this study suggest the possibility of prompting and balancing the use of the preterite and imperfect when writing a fictional narrative.

\section{CONCLUSIONS AND RECOMMENDATIONS FOR FURTHER RESEARCH}

Instruction that employs web 2.0 technology in writing tasks provides a better learning context that can prompt students to learn the distinctions between the Spanish preterite and imperfect at an early stage of their interlanguage development. These findings are important because previous studies have stated that at an early stage of learning, the preterite emerges as the default marker of past tense. Imperfect morphology is rare or appears later than the preterite (Salaberry, 2000); however, these results suggest the possibility of stimulating a balanced or equal emergence of both structures for recognition. The latter confirms what was previously stated in a similar study conducted by the author (Castañeda, 2011). In addition, these results also suggest that for a technology to be effective in this type of activity, it must have an interface that allows students to interact and share their ideas, photos, or visuals instead of having an interface that is one-sided and 
noncommunicative. In sum, web 2.0 technologies may be more appropriate to implement this specific type of writing activity than an electronic workbook.

As language-learning software develops, instructors must take into consideration that technology, when used appropriately, provides a richer contextual environment for learning difficult structures in a second language. As L2 teachers and learners transition into the use of web 2.0 technologies, electronic books, and workbooks, knowing which tools help students develop specific skills more effectively gains importance. Further research should be conducted about how additional technologies can help teachers and students with other problematic grammar structures in lower- and upper-division courses.

\section{ACKNOWLEDGMENTS}

I would like to thank my anonymous reviewers for their valuable comments and observations and the editor (s) of the International Association for Language Learning Technology Journal for their help in this process. I would also like to thank my colleagues Debra Shelestak, Leslie Heaphy, and Frances Novack for their comments on earlier versions. My sincere gratitude to my colleagues Lori McGee, Mason Shuman, and Cindy Trocchio for their valuable help on this project. Any errors in content are mine alone.

\section{About the Author}

Daniel A. Castaneda, Ed. D., is an assistant professor of Spanish at Kent State University, Stark Campus. Dr. Castaneda's research interests include the application of synchronous and asynchronous text-based technologies in the teaching and learning of a foreign language. 
Casteneda

\section{REFERENCES}

Andersen, R. W. (1991). Developmental sequences: The emergence of aspect marking in second language acquisition. In T. Huebner \& C. A. Ferguson (Eds.), Crosscurrents in second language acquisition and linguistic theories (pp. 305-324). Philadelphia, PA: John Benjamins.

Arnold, N., Ducate, L., \& Kost, C. (2009). Collaborative writing in wikis: Insights from culture projects in German classes. In L. Lomicka \& G. Lord (Eds.), The next generation: Social networking and online collaboration in foreign language learning (pp. 115-144). San Marcos, TX: CALICO.

Aronsson, L. (2002). Operation of a large scale, general purpose wiki website. Experience from susning.nu's first nine months in service. Proceedings of the $6^{\text {th }}$ International ICCCC/IFIP Conference on Electronic Publishing, Czech Republic, 27-37. Retrieved from http://aronsson.se/wikipaper.html

Augar, N., Raitman, R., \& Zhou, W. (2004). Teaching and learning online with wikis. In R. Atkinson, C. McBeath, D. Jonas-Dwyer, \& R. Phillips (Eds.), Beyond the comfort zone: Proceedings of the $21^{\text {st }}$ ASCILITE Conference (pp. 95-104). Perth, Australia: ASCILITE. Retrieved from http://www.ascilite.org.au/conferences/perth04/procs/augar.html

Bakar, N. A. (2009). E-learning environment: Blogging as a platform for language learning. European Journal of Social Sciences, 9(4), 594-604. Retrieved from http://www.eurojournals.com/ejss_9_4_07.pdf

Bardovi-Harlig, K. (1994). Anecdote or evidence? Evaluating support for hypotheses concerning the development of tense and aspect. In E. E. Tarone, S. M. Gass, \& A. D. Cohen (Eds.), Research methodology in second-language acquisition (pp. 41-60). Hillsdale, NJ: Erlbaum.

Bardovi-Harlig, K. (1998). Narrative structure and lexical aspect: Conspiring factors in second language acquisition of tense-aspect morphology. Studies in Second Language Acquisition 20, 471-508.

Bardovi-Harlig, K. (2005). Tracking the elusive imperfect in adult L2 acquisition. In P. Kempchinsky \& R. Slabakoba (Eds.), Aspectual inquiries (pp. 397-419). Dordrecht, Netherlands: Springer. Retrieved from http://www.springerlink.com/content/n16m1312757nw301/fulltext.pdf 
Bloch, J. (2007). Abdullah's blogging: A generation 1.5 student enters the blogosphere. Language Learning and Technology 11(2) 128-141. Retrieved from http://1lt.msu.edu/vol11num2/bloch/

Blyth, C. (2005). From empirical findings to the teaching of aspectual distinctions. In D. Ayoun \& M. R. Salaberry (Eds.), Tense and aspect in romance languages (pp. 211-252). Amsterdam, Netherlands: John Benjamins.

Bryant, T. (2006). Social software in academia. EDUCAUSE Quarterly, 29(2), 6164. Retrieved from http://net.educause.edu/ir/library/pdf/eqm0627.pdf

Campbell, A. P. (2003).Weblogs for use with ESL classes. The Internet TESL Journal, 9(2), 1-4. Retrieved from http://iteslj.org/Techniques/Campbellweblogs.html

Castañeda, D. A. (2011). The effects of instruction enhanced by video/photo blogs and wikis on learning the distinctions of the Spanish preterite and imperfect. Foreign Language Annals, 44(4), 692-711.

Castaneda, D.A., Ahern, T. \& Díaz, S. (2011). Teaching and learning the Spanish aspect using blogs and wikis: An exploratory study. The International Association for Language Learning Technology Journal, 41(1) 64-89.

Comajoan, L. (2005). The early L2 acquisition of past morphology: Perfective morphology as an aspectual marker or default tense marker? Selected Proceedings of the 6th Conference on the Acquisition of Spanish and Portuguese as First and Second Languages, 31-43. Somerville, MA: Cascadilla Proceedings Project.

Dobeli, B. (2005). Wikis: A rapidly growing phenomenon in the German-speaking school community. Proceedings of the 2005 International Symposium on Wikis and Open Collaboration, San Diego, CA. 113-116. Retrieved from http://portal.acm.org/dl.cfm

Downes, S. (2004). Educational blogging. EDUCAUSE Review, 39(5), 14-26. Retrieved from http://net.educause.edu/ir/library/pdf/ERM0450.pdf

Ducate, L. C., \& Lomicka, L.L. (2005). Exploring the blogosphere: Use of web logs in the foreign language classroom. Foreign Language Annals, 38(3), 410421. Retrieved from http://www.actfl.org/files/members/3Q_2005/3Q05_08Ducate.pdf 
Casteneda

Duffy, P., \& Bruns, A. (2006). The use of blogs, wikis, and RSS in education: A conversation of possibilities. Online Learning and Teaching Conference, Brisbane, Australia. 31-38. Retrieved from http://eprints.qut.edu.au/5398/1/5398.pdf

Frantzen, D. (1995). Preterite/imperfect half-truths: Problems with Spanish textbook rules for usage. Hispania, 78(1), 145-158.

Godwin-Jones, R. (2003). Blogs and wikis: Environments for on-line collaboration. Language Learning \& Technology, 7(2), 12-16. Retrieved from http://lit.msu.edu/ vol7num2/ emerging/

Godwin-Jones, R. (2007). Digital video update: YouTube, flash, high-definition. Language Learning \& Technology 11(1), 16-21. Retrieved from http://ltt.msu.edu/vol11 num1/ emerging/

Hinkle, D., Wiersma, W., \& Jurs, S. (2003). Applied statistics for the behavioral sciences. New York, NY: Houghton Mifflin.

Hopper, P. J. (1979). Aspect and foregrounding in discourse. In T. Givon (Ed.), Syntax and semantics: Discourse and syntax (pp. 213-241). New York, NY: Academic Press.

Huffaker, D. (2005). The educated blogger: Using weblogs to promote literacy in the classroom. AACE Journal, 13(2), 91-98.

Johnson, A. (2004). Creating a writing course utilizing class and student blogs. The Internet TESL Journal, 10(8). Retrieved from http://iteslj.org/Techniques/Johnson-Blogs/

Kessler, G. (2009). Student-initiated attention to form in wiki-based collaborative writing. Language Learning \& Technology, 13 (1), 79-95. Retrieved from http://1lt.msu.edu/vol13num1/kessler.pdf

Konieczny, P. (2007). Wikis and wikipedia as a teaching tool. International Journal of Instructional Technology and Distance Learning, 4(1), 15-33. Retrieved from http://www.itdl.org/Journal/Jan_07/article02.htm

Lafford, P. A., \& Lafford, B. A. (2005). CMC technologies for teaching foreign languages: What is on the horizon? CALICO Journal, 22(3), 679-709. Retrieved from https://www.calico.org/html/article_162.pdf 
Le Ho, G. A. (2009). Blogging and Vietnamese language teaching and learning. Electronic Journal of Foreign Language Teaching, 6(1), 268-277. Retrieved from http://e-flt.nus.edu.sg/v6sp12009/ho.htm

Lee, L. (2009). Promoting intercultural exchanges with blogs and podcasting: A study of Spanish-American telecollaboration. Computer Assisted Language Learning, 22(5), 425-443. doi: 10.1080/09588220903345184

Lee, L. (2010a). Exploring wiki-mediated collaborative writing: A case study in an elementary Spanish course. CALICO Journal, 27(2), 260-276.

Lee, L. (2010b). Fostering reflective writing and interactive exchange through blogging in an advanced language course. ReCALL, 22(2), 212-225.

Leuf, B., \& Cunningham, W. (2001). The wiki way: Quick collaboration on the web. Boston, MA: Addison Wesley.

Liskin-Gasparro, J. (2000). The use of tense-aspect morphology in Spanish oral narratives. Hispania, 83(4), 830-844.

Lopez-Ortega, N. (2000). Tense, aspect, and narrative structure in Spanish as a second language. Hispania, 83(3), 488-502.

Luce-Kapler, R. (2007). Radical change and wikis: Teaching new literacies. Journal of Adolescent and Adult Literacy, 51(3), 214-223.

Lund, A. (2008). Wikis: A collective approach to language production. ReCALL 20(1), 35-54. Retrieved from http://journals.cambridge.org/action/displayAbstract?fromPage $=$ online\&aid $=1584900$

McIntosh, E. (2005). From learning logs to learning blogs. Scottish Center for Information on Language Teaching and Research. Retrieved from http://www.strath.ac.uk/media/departments/curricularstudies/scilt/slr/issues/ 13/SLR13_McIntosh.pdf

Montero-Fleta, B., \& Perez-Sabater, C. (2010). A research on blogging as a platform to enhance language skills. Procedia Social and Behavioral Sciences, Spain 2(2), 773-777. doi: 10.1016/j.sbspro.2010.03.100

Montrul, S., \& Slabakova, R. (1999). On viewpoint aspect interpretation and its L2 acquisition: A UG perspective. In Y. Shirai \& M. R. Salaberry (Eds.), The 
Casteneda

L2 Acquisition of Tense-Aspect Morphology (pp. 363-395). Amsterdam, Netherlands: John Benjamins.

Mynard, J. (2007a). A blog as a tool for reflection for English language learners. Professional Teaching Articles. Retrieved from http://www.asian-efljournal.com/pta_Nov_07_jm.pdf

Mynard, J. (2007b). How blogging can promote learner autonomy. In Proceedings of the Independent Learning Association 2007 Japan Conference: Exploring Theory, Enhancing Practice: Autonomy Across the Disciplines, Japan. Retrieved from http://independentlearning.org/ILA/ila07/files/ILA2007_030.pdf

Oskoz, A., \& Elola, I. (2010). Meeting at the wiki: The new arena for collaborative writing in foreign language courses. In C. McLoughlin \& M. Lee (Eds.), Web 2.0-based e-learning: Applying social informatics for tertiary teaching (pp. 209-227). Hershey, PA: IGI Global.

Ozete, O. (1988). Focusing on the preterite and imperfect. Hispania, 71(3), 687691.

Pae, J.-K. (2007). Wiki-based English writing: Its effects on English writing proficiency and anxiety and Korean learner's perceptions. MultimediaAssisted Language Learning, 10(1), 81-105.

Parker, K. R., \& Chao, J. T. (2007). Wiki as a teaching tool. Interdisciplinary Journal of Knowledge and Learning Objects, 3, 57-72. Retrieved from http://ijklo.org/Volume3/IJKLOv3p057-072Parker284.pdf

Rubio, D., Berg-Weger, M., Tebb, S., Lee, S. \& Rauch, S. (2003). Objectifying content validity: Conducting a content validity study in social work research. Social Work Research 27(2), 94-104. Retrieved from EBSCOhost database.

Salaberry, M. R. (2000) The development of past tense morphology in L2 Spanish. Philadelphia, PA: John Benjamins.

Salaberry, M. R., (2003). Tense aspect in verbal morphology. Hispania, 86(3), 559573.

Sykes, J. M., Oskoz, A., \& Thorne, S. L. (2008). Web 2.0, synthetic immersive environments, and mobile resources for language education. CALICO 
Using Web 2.0 ...

Journal, $\quad 25(3), \quad$ 528-546. $\quad$ Retrieved from https://www.calico.org/html/article_715.pdf

Sze, P. (2008). Online collaborative writing using wikis. The Internet TESL Journal, 14(1), 1-5. Retrieved from http://iteslj/techniques/sze-wikis.html

Thorne, S., \& Payne, J. S. (2005). Evolutionary trajectories, Internet-mediated expression, and language education. CALICO Journal, 22(3), 371-397.

Vendler, Z. (1967). Linguistics in Philosophy. Ithaca, NY: Cornell University Press.

Westfall, R., \& Forester, S. (1996). Beyond aspect: New strategies for teaching the preterite and the imperfect. Hispania, 79(3), 550-560.

Zeinstejer, R. (2008). The wiki revolution: A challenge to traditional education. The Internet TESL Journal, 11(4), 1-6. Retrieved from http://teslej.org/ej44/m1.pdf 


\section{APpendiX A}

\section{Pre-and Post-Test (recognition component)}

Please, watch the video clip and then circle the best option according to the context. You will have 6 to 10 minutes to complete the task. You will be told when 2 minutes are left.

En el video (1 hay/ hubo/ había/ haber) tres osos que (2 viven/ vivieron/vivían/vivir) en una casita bonita en el bosque. Se (3 llaman/ llamaron/ llamaban/ llamar) Papá Oso, Mamá Osa, y Pequeño Osito. Papá Oso (4 es/ fue/ era/ ser) bajo, gordo y feo. (5 Tiene/ Tuvo/ Tenía/ Tener) pelo marrón oscuro y siempre (6 esta/ estuvo/ estaba/ estar) de mal humor. Mamá Osa (7 es/ fue/ era/ ser) agradable y no ( 8 habla/ habló/ hablaba/ hablar) mucho. Siempre (9 lleva/ llevó/ llevaba/llevar) un vestido y un gorro de dormir. El Pequeño Osito (10 es/ fue/ era/ ser) un bebé grande y siempre (11 lleva/ llevó/ llevaba/ llevar) un pañal.

Una mañana mientras ellos (12 desayunan/ desayunaron/ desayunaban/ desayunar), el Pequeño Osito (13 come/ comió/ comía/comer) toda la miel y el papá lo (14 golpea/golpeó/golpeaba/golpear) y el Osito (15 llora/ lloró/ lloraba/ llorar). Luego el papá (16 sale/ salió/ salía/salir) de la cocina con el bebé para buscar más miel. (17 Encuentran/ Encontraron/ Encontraban/ Encontrar) una colmena en un árbol que (18 está/ estuvo/ estaba/estar) cerca de la casita. El árbol (19 es/ fue/ era/ ser) muy alto y delgado y la colmena (20 es/ fue/ era/ser) grande. Ellos (21 intentan/intentaron/intentaban/ intentar) diferentes maneras para obtener la miel de la colmena. Primero, el papá (22 utiliza/ utilizó/ utilizaba/ utilizar) una escalera, (23 salta/ saltó/ saltaba/saltar) desde un balancín y (24 carga/ cargó/ cargaba/ cargar) a la mamá y al bebé sobre sus hombros. Después, (25 camina/ caminó/ caminaba/ caminar) sobre una cuerda y finalmente ( 26 sube/ subió/ subía/ subir) al árbol con zapatos especiales. Papá oso ( 27 fracasa/ fracasó/ fracasaba/ fracasar) en todos sus intentos y al final (28 llora/ lloró/ lloraba/ llorar) de frustración porque (29 descubre/ descubrió/ descubría/ descubrir) que Mamá Osa (30 tiene/ tuvo/ tenía/ tener) mucha miel en la despensa.

\section{Translation}

In the video there ( 1 to be ) three bears that ( 2 to live) in a nice little house in the woods. They were ( 3 to call) Father Oso, Mother Osa, and Little Osito. Father Oso (4 to be) short, fat and ugly. He (5 to have) brown dark hair and he (6 to be) 
always in a bad mood. Mother Osa ( 7 to be) agreeable and did not ( 8 to speak) much. She always ( 9 to wear) a dress and a sleeping hat. The little Osito (10 to be) a big baby and always (11 to wear) a diaper.

One morning while they were (12 to eat breakfast), The Little Osito (13 to eat) all the honey and his father (14 to hit) him and the Little Osito (15 to cry). Then, the father (16 to leave) from the kitchen with the baby bear to look for more honey. They (17 to find) a beehive in a tree that (18 to be) near the house. The tree (19 to be) tall and thin and the beehive ( 20 to be) big. The father and the baby (21 to try) different ways to get the honey from the beehive. First, the father (22 to use) a ladder, he (23 to jump) from a seesaw and he (24 to carry) the mother and the baby on his shoulders. After that, he (25 to walk) on a rope and finally he (26 to climb) a tree with especial shoes. Father Oso (27 to fail) all his attempts and in the end he (28 to cry) of frustration because he (29 to find out) that Mother Osa (30 to have) a lot of honey in the pantry. 


\section{APPENDIX B}

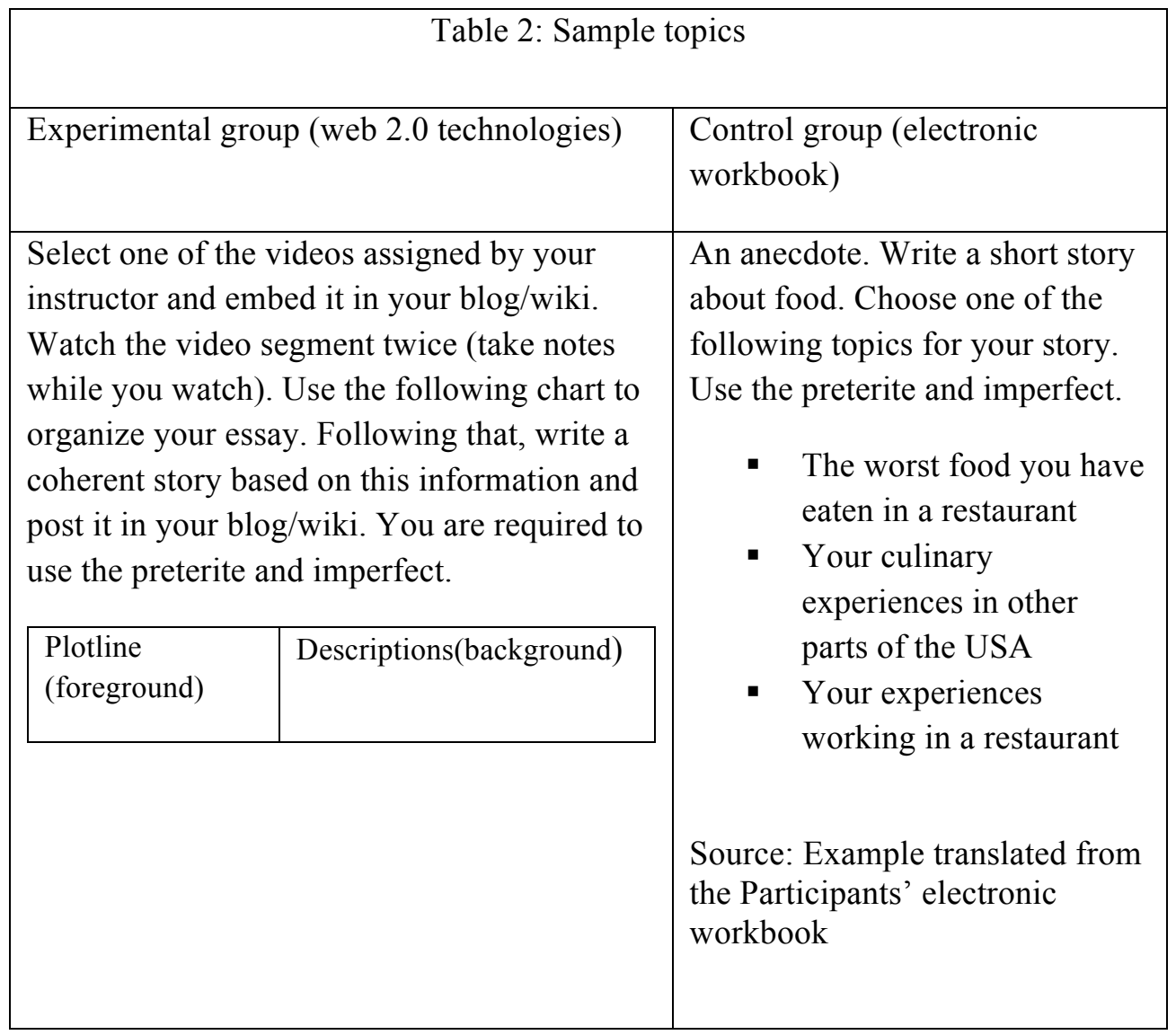

